\title{
A Genetic Algorithm-Based Model for Inventory Control in Intermittent Demands
}

\author{
Ferhat Yuna $^{1 *}$, Burak Erkayman ${ }^{2}$, \\ ${ }^{1 *}$ Atatürk Üniversitesi, Mühendislik Fakültesi, Endüstri Mühendisliği Bölümü, Erzurum, Türkiye, (ORCID: 0000-0001-8085-2841), ferhat.yuna@atauni.edu.tr \\ 2 Atatürk Üniversitesi, Mühendislik Fakültesi, Endüstri Mühendisliği Bölümü, Erzurum, Türkiye, (ORCID: 0000-0002-9551-2679), erkayman@atauni.edu.tr
}

(International Conference on Design, Research and Development (RDCONF) 2021 - 15-18 December 2021)

(DOI: 10.31590 /ejosat.1039251)

ATIF/REFERENCE: Yuna, F. \& Erkayman, B. (2021). A Genetic Algorithm-Based Model for Inventory Control in Intermittent Demands. European Journal of Science and Technology, (32), 696-701.

\begin{abstract}
Demand forecasting is a difficult field of study for intermittent demands. Spare parts demand structures also have an intermittent demand structure. Therefore, for companies operating in this field, this situation causes various problems (holding cost or cost of lost sale). Intermittent demands are inherently difficult to predict. Demands with a smooth structure provide a more suitable working environment for businesses. Because the more accurately the relevant demand is forecasted, the more smoothly the works that depend on demand forecasting are carried on. In this study, a randomly generated demand series with intermittent demand structure is examined. The estimation difficulty of intermittent demand is illustrated by an estimation made in Matlab. In order to avoid this difficulty, the costs were tried to be minimized by determining the inventory levels. An inventory model is proposed that determines stock levels using intermittent demands and calculates average profit by calculating costs. The related model was solved with Genetic Algorithm in Matlab and the results were recorded.
\end{abstract}

Keywords: Genetic Algorithm, Intermittent Demand, Inventory Control, Optimization.

\section{Aralıklı Taleplerde Envanter Kontrolü için Genetik Algoritmaya Dayalı Bir Model}

$\ddot{O} \mathbf{z}$

Talep tahmini, aralıklı talepler için zor bir çalışma alanıdır. Yedek parça talep yapıları da aralıklı bir talep yapısına sahiptir. Dolayısıyla bu alanda faaliyet gösteren firmalar için bu durum çeşitli sorunlara (elde tutma maliyeti veya kayıp satış maliyeti) neden olmaktadır. Aralıklı talepleri tahmin etmek doğal olarak zordur. Düzgün bir yapıya sahip talepler, işletmeler için daha uygun bir çalışma ortamı sağlar. İlgili talep ne kadar doğru tahmin edilirse, talep tahminine dayalı çalışmalar da o kadar sorunsuz yürütülür. Bu çalışmada, aralıklı talep yapısı ile rastgele oluşturulmuş bir talep serisi incelenmiştir. Aralıklı talebin tahmin zorluğu, Matlab'da yapılan bir tahminle gösterilmiştir. Bu zorluğun önüne geçebilmek için stok seviyeleri belirlenerek maliyetler minimize edilmeye çalışılmıştır. Aralıklı talepleri kullanarak stok seviyelerini belirleyen ve maliyetleri hesaplayarak ortalama karı hesaplayan bir envanter modeli önerilmiştir. İlgili model Matlab'da Genetik Algoritma ile çözülmüş ve sonuçlar kaydedilmiştir.

Anahtar Kelimeler: Genetik Algoritma, Aralıklı Talep, Envanter Kontrol, Optimizasyon.

\footnotetext{
*Sorumlu Yazar: ferhat.yuna@atauni.edu.tr
} 


\section{Introduction}

Subjects such as inventory planning and demand forecasting are areas that offer an opportunity to be one step ahead among the companies in the market. The results of the studies in these areas directly affect the success and the loyalty of the customers interacted in the market increases. But demand forecasting does not always yield good results. Intermittent demand is an example of this situation. In this case, there may be disruptions in production or supply processes due to estimation errors. Related disruptions occur as costs.

It is easier to predict smooth demands than intermittent demands (Saatçioğlu \& Özçakar). In this difference, one of the parts that affect the result of the forecast is that the demand structure is intermittent. The second is the variability in the size of demand. In this case, in order to reduce costs, different approaches should be applied by abandoning the difficult estimation situation. If the aim is to reduce costs, negative situations caused by the variability in intermittent demand can be met with an inventory model suitable for the problem.

Firms are affected by many parameters while holding stock. These parameters, from stock levels to costs, affect the process. This is important when determining inventory policies (Yuna \& Erkayman, 2019). Every company wants to make a profit. Therefore, this commercial thinking affects the behavior of firms in the market. The desire to make profit emerges as the desire to reduce costs. Having too many raw materials or products, or vice versa, not having enough of the related products creates extra costs. Ensuring the balance between these two options creates a positive picture for companies.

In this study, the difficulty of intermittent demand forecasting was revealed, profit maximization was carried out with the help of inventory model and genetic algorithm, and stock limits were found for intermittent demand.

\section{Material and Method}

\subsection{Literature Review}

The special case in which the demands are intermittent creates the need to study the intermittent demands separately. The network analysis study for the "intermittent demand" keyword was prepared using the Web of Science database with the VOSviewer package program. The network analysis generated with the keyword "intermittent demand" is shown in Figure 1 below.

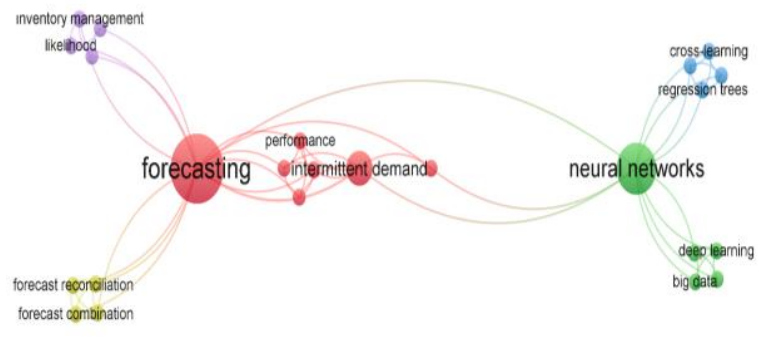

Fig. 1. Network analysis for the intermittent demand keyword.

The keywords associated with intermittent demand and common workspace are shown in Figure 1 as a network.
An experimental study was conducted by Babai et al. on demand data from approximately 3000 stock units in the automotive industry to analyze the performance of four forecasting methods with numerical research (M. Babai, Chen, Syntetos, \& Lengu, 2020). The bullwhip effect in the automotive spare parts supply chain was defined to learn how demand variability spreads in different products by Pastore et al. More than 30,000 products were evaluated, taking into account different technical specifications, demand categories, and planning parameters (Pastore, Alfieri, \& Zotteri, 2019).

The study by M. Hasni et al. is based on large data sets consisting of 7000 stock keeping units. In particular, an approach has been developed to deal with intermittent demands. In this approach, demand data is sampled using a Markov chain to switch between demand periods (Hasni, Babai, Aguir, \& Jemai, 2019). Van der Auweraer and Boute focused on inventory management of critical spare parts used for service maintenance. These spare parts are generally expressed with a wide variety and intermittent demand structure. A method has been developed to estimate the demand for these spare parts by adhering to the maintenance policy (Van der Auweraer \& Boute, 2019).

To determine the spare parts stock levels, it is necessary to estimate the spare part demand of the original equipment manufacturer (OEM). Due to an inaccuracy in the product listing, the spare parts demand forecast may be more or less than the actual demand. This situation significantly affects stock levels. In a recent study by Stip \& Van Houtum involved, a method has been developed to generate warnings for possible errors. With this method, the percentage of not finding spare parts in the relevant company has been reduced by approximately 4-5 percent during the year (Stip \& Van Houtum, 2020). Boutselis and McNaught worked on the problem of forecasting spare parts demand related to equipment failures within some Logistics Support Organizations (LSOs) (Boutselis \& McNaught, 2019). A detailed examination by Jiang et al. showed that an adaptive univariate SVM (AUSVM) model was created to estimate the intermittent demand. With real-world data from the heavy vehicle spare parts company, the effectiveness of the proposed model compared to 12 currently known models and a neural network has been demonstrated. A good level of performance has been achieved in inventory performance and statistical accuracy with the AUSVM model (Jiang, Huang, \& Liu, 2020).

In Lolli et al.'s paper, different architectures and input models were combined and compared with neural networks for intermittent demand in real-time series. Subsequently, an analysis of the study performed statistically to verify the most feasible and best performance (Lolli et al., 2017). The focus of the study prepared by Petropoulos et al. is forecasting for intermittent demand data. As a standard, instead of temporal summation, the summation is made on demand volumes. Thus, an approach for intermittent demand estimation is introduced. Additionally, a simulation was run for stock control (Petropoulos, Kourentzes, \& Nikolopoulos, 2016). There are many studies in the literature to determine the inventory levels. Most studies are based on the Croston method, depending on the amount of demand and the time between arrivals. The empirical power of forecasting methods for intermittent demand was investigated in 2014 by Babai et al. The research focused on the effects of smoothing constant values. In addition, the study was observed by experimenting with data from the military and automotive industry (M. Z. Babai, Syntetos, \& Teunter, 2014). 


\subsection{Categorization of Demand Patterns}

Demands occur mostly at irregular time intervals $\left(t_{i}\right)$ and at different amounts $\left(\varepsilon_{i}\right)$, where $\varepsilon_{i}$ is the spare part demand amount and $t_{i}$ is the time interval between two consecutive demands.

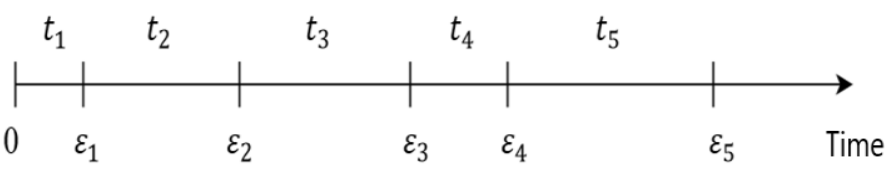

Fig. 2. An example of a spare part demand (Özçift, 2018)

For the demands, two parameters are introduced to evaluate both the concept of quantity and time. These parameters are:

Average Demand Interval (ADI): While calculating the average demand interval, demand regularity is measured by calculating the average interval between two demands for a spare part.

Coefficient of Variance (CV): This coefficient is the change in the standard deviation of the demand amount compared to the average of the demand.

$A D I=\frac{\sum_{i=1}^{N} t_{i}}{N}$

$\varepsilon=\frac{\sum_{i=1}^{N} \varepsilon_{i}}{N}$

$C V=\frac{\sqrt{\frac{\sum_{i=1}^{n}\left(\varepsilon_{i}-\varepsilon\right)^{2}}{N}}}{\varepsilon}$

In Equation (1), where $\mathrm{N}$ represents the number of all periods. In Equation (3), where $\mathrm{N}$ represents the number of periods having non-zero demand.

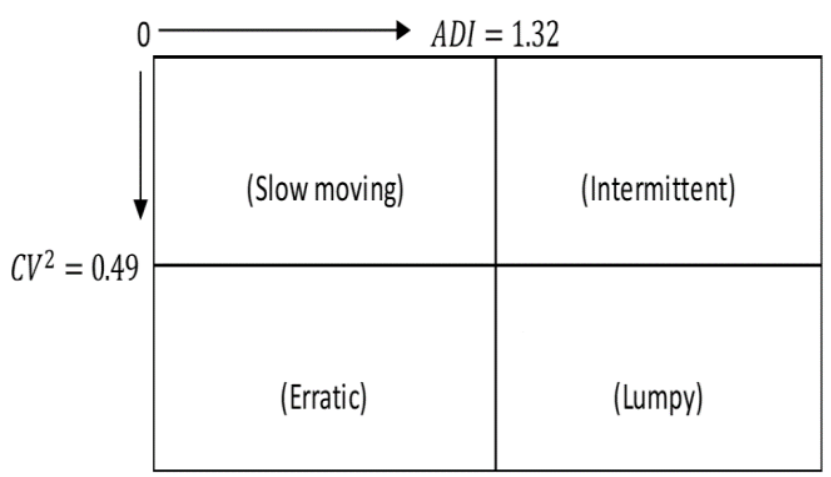

Fig. 3. Spare parts product demand classification

The intermittent nature of the demand can be traced to four basic features, as shown in Figure 3 (Syntetos, 2001).

- Slow-moving demand is the form of demand where the intervals and quantities between demands do not change significantly.

- Intermittent demand is a form of a demand that does not vary much in the amount of demand, but there is no demand for most of the time period.

- Erratic demand is highly non-uniform in terms of the amount of demand rather than the intervals between demands.

- Lumpy demand maintains zero demand over many time frames and demand values vary greatly.

\subsection{Genetic Algorithm Based Inventory Model}

The Genetic Algorithm (GA) is a population-based algorithm first developed by John Holland and his student David Goldberg (Haddow \& Tufte, 2010), inspired by genetic inheritance, and has been applied to optimization problems.

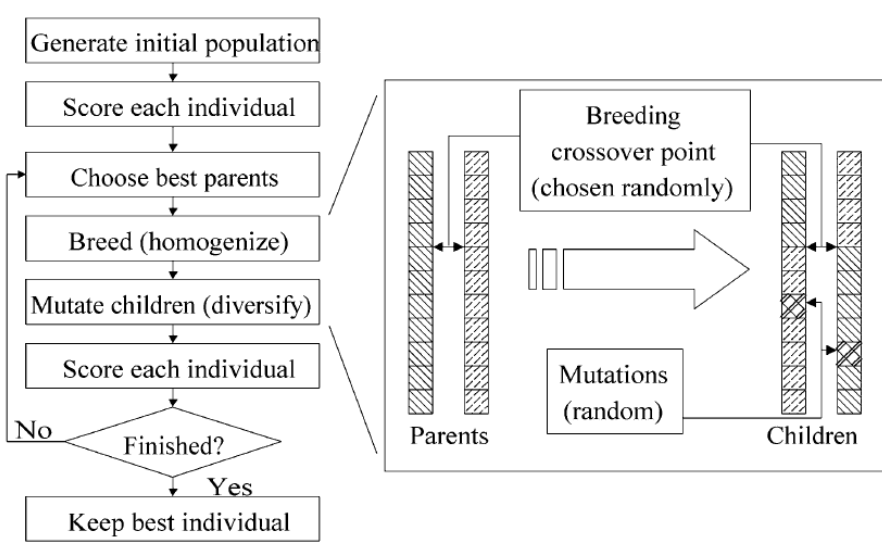

Fig. 4. Flowchart of the genetic algorithm (Boeringer \& Werner, 2004).

A genetic algorithm-based inventory model was proposed to avoid the difficulty and cost of intermittent demand. According to the relevant model demand structure, it finds a stock lower and upper limit for the demand that operates with the aim of minimizing costs. The created model works with the following acceptance, assumption, parameters, and steps of the model. The proposed model was created in Matlab in accordance with the Genetic Algorithm as a function.

Table 1. Costs used in the model

\begin{tabular}{|c|c|c|c|c|}
\hline $\begin{array}{c}\text { Product } \\
\text { Price (*k) }\end{array}$ & $\begin{array}{c}\text { Lead } \\
\text { Time }\end{array}$ & $\begin{array}{c}\text { Ordering } \\
\text { Cost }\end{array}$ & $\begin{array}{c}\text { Inventory } \\
\text { Cost }\end{array}$ & $\begin{array}{c}\text { Lost Sales } \\
\text { Cost }\end{array}$ \\
\hline 10 & 1 & $15 * \mathrm{k}$ & $0,02 * \mathrm{k}$ & $0,04 * \mathrm{k}$ \\
\hline
\end{tabular}

The costs used in the inventory model are defined as a ratio of each other. All costs can be calculated as a ratio of the product price $(\mathrm{k})$. When the product price $(\mathrm{k})$ is changed, other costs will be updated in the same way. The inventory model has been prepared flexibly. In other words, it provides the opportunity to make changes such as lead time, all costs, product lifetimes, and different demand structures. This ability of the inventory model will facilitate future studies. Because it may be necessary to update the model for different situations, different demand structures, and different strategies. The model is repeated as long as the period length of demand data generated randomly or collected from real life. The aim of the model is to increase the average profit by determining different stock limits.

The inventory model works with demand that belongs to the intermittent demand class. It calculates cost and profit according to defined parameters. It meets the demands from stocks and records the met quantities as sales. If there is an unmet demand, it records them as lost sales. If the stock amount is below the lower stock limit, an order is opened. The order is opened in such a way that the on-hand stock does not exceed the upper stock limit.

\subsection{Assumptions, Variables and Parameters}

The parameters and the decision variables are given in Table 2 and Table 3. 
- The model works with a certain number of periods.

- The demands are derived randomly as much as the number of periods.

- The products used from the stocks are used according to the FIFO rule.

- The orders are added to the end of period stocks in accordance with the lead time.

Table 2. Decision variables

\begin{tabular}{|c|l|}
\hline Variables & Description \\
\hline$I_{l b}$ & Lower stock limit \\
\hline$I_{u b}$ & Upper stock limit \\
\hline$y_{i}$ & Order check \\
\hline$S_{i}$ & Sales of period $i$ \\
\hline$O_{i}$ & Orders of period $i$ \\
\hline$I_{i}$ & Stock of period $i$ \\
\hline$L S_{i}$ & Lost sales of period $i$ \\
\hline
\end{tabular}

Table 3. Parameters

\begin{tabular}{|c|l|}
\hline Parameters & Description \\
\hline$Q$ & Order quantity \\
\hline$T$ & Number of periods \\
\hline$L$ & Lead time \\
\hline$C_{P}$ & Product cost \\
\hline$C_{O}$ & Ordering cost \\
\hline$C_{h}$ & Inventory holding cost \\
\hline$C_{l s}$ & Lost sales cost \\
\hline$P$ & Sale price \\
\hline$D_{i}$ & Customer demands of period $i$ \\
\hline
\end{tabular}

The fitness function of the proposed model is as follows:

$\operatorname{Max} \sum_{i=15}^{T} P S_{i}-\left(C_{P} O_{i}+C_{l s} L S_{i}+C_{h} I_{i}+C_{o} y_{i}\right)$

$y_{i}= \begin{cases}1 & \text { if ordered } \\ 0 & \text { otherwise }\end{cases}$

$i=15,16, \ldots T$

The first 15 periods were assumed to be the warm-up period. Therefore, the i value was initialized from 15 .

\subsection{Application}

This paper reviews randomly generated 250-period intermittent demand data. The demand class was determined according to the formulas given in Equation (1) and Equation (3) and demand estimation was made for the determined demand class. While demand estimation was made, all estimators in Regression Learner App in Matlab were run and the estimator with the best result was determined. After the demand class was determined and the estimated demand was made, a function based on a Genetic Algorithm was created and an inventory model was proposed.

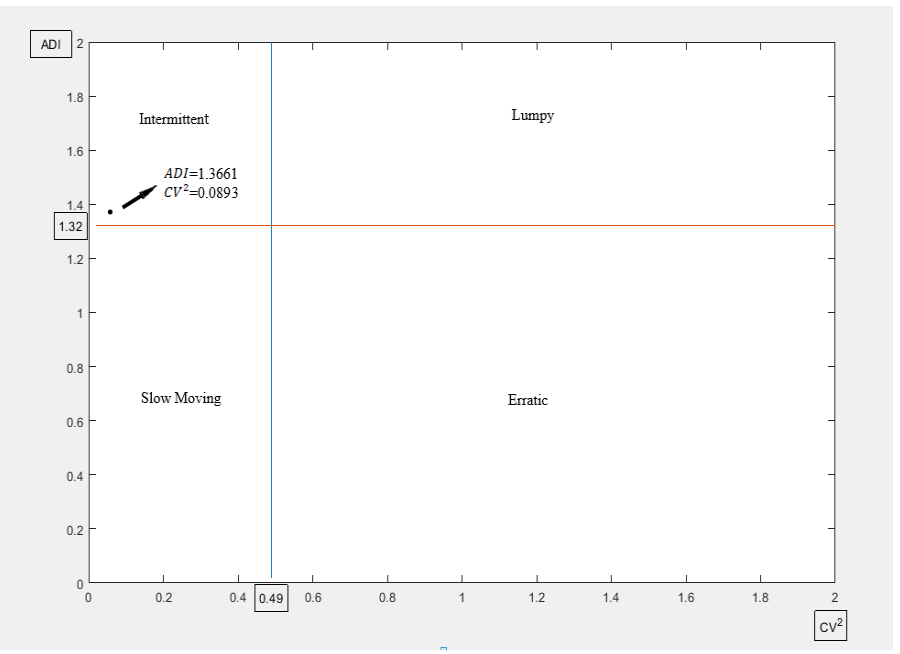

Fig. 5. Classification chart of demand

The demand data used belongs to the intermittent demand class according to the calculations given in Equation (1) and Equation (3). The ADI value of the demand was calculated as 1.3661 and the value of $C V^{2}$ as 0.0893 . Considering the difficulty of estimating the intermittent demand, it is aimed to determine lower and upper stock limits for this random demand produced rather than estimation. In this study, the difficulty of estimating the intermittent demand using Regression Learner Application on Matlab before the model proposal has been demonstrated.

\subsection{Results}

As mentioned, intermittent demand forecasting is a difficult issue. Difficulty in demand estimation brings about an increase in costs along with inaccurate demand estimates. Demand forecasting was made using Regression Learner App on Matlab with the random demand of 250 units. All estimators available in Regression Learner App were run for two different validation values $(7 \%$ and $25 \%)$. Then the results are reported.

When the Regression Learner App is run with 25\% validation, the Exponential Gaussian Process Regression model gives the best estimate among the other estimators in the Regression Learner App with values of 0.32 (R-Squared) and 12.828 (RMSE). In Figure 6, the estimation values are shown graphically.

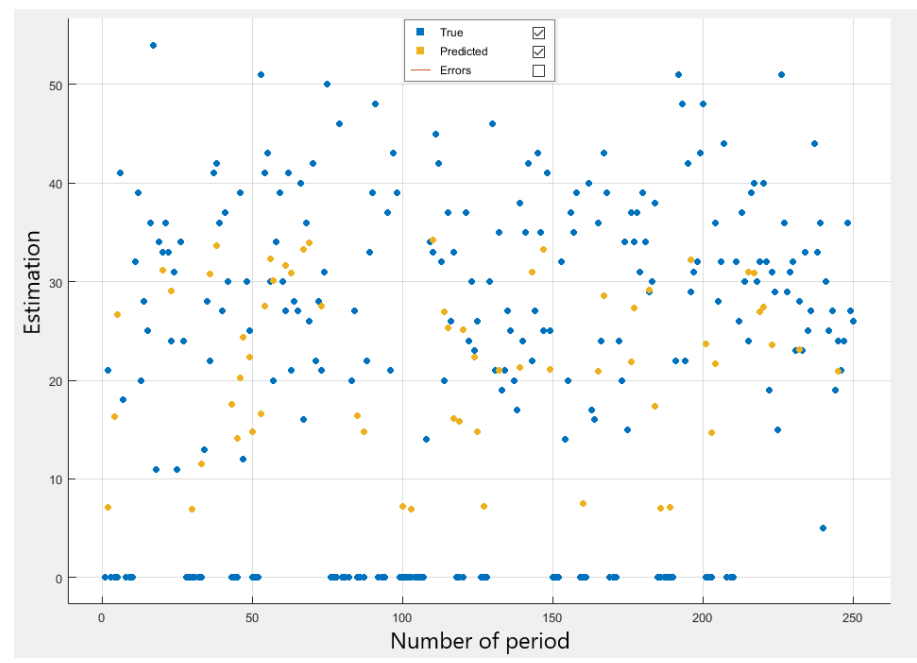

Fig. 6. Predictions with $25 \%$ validation 
When the Regression Learner App is run with 7\% validation, the Squared Exponential Gaussian Process Regression model gives the best estimate among the other estimators in the Regression Learner App with values of 0.29 (R-Squared) and 13.465 (RMSE). In Figure 7, the estimation values are shown graphically.

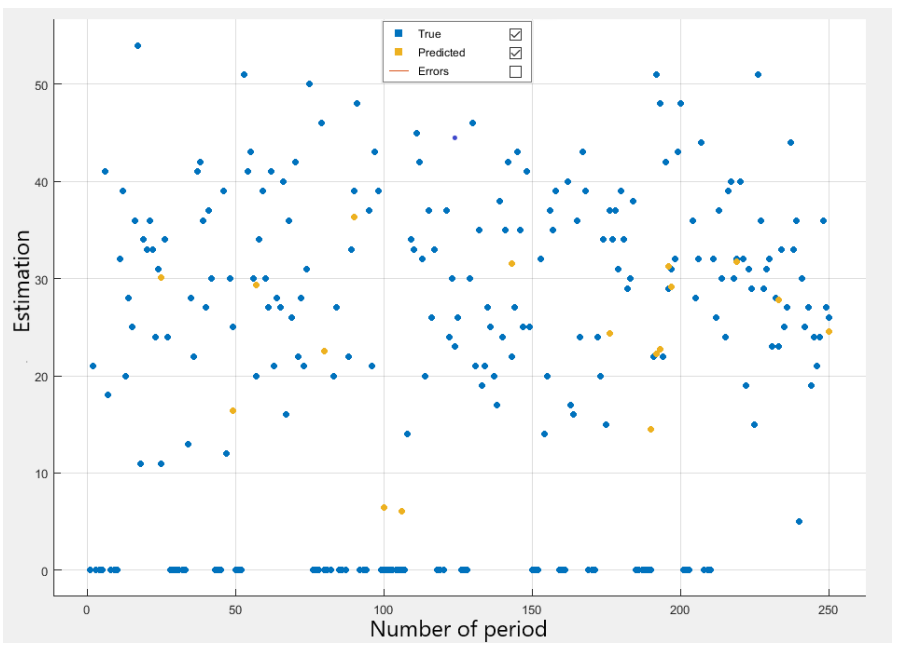

Fig. 7. Predictions with $7 \%$ validation

As can be seen in Figure 6 and Figure 7, estimation values do not give good results. In this context, a Genetic Algorithm-based inventory model is recommended instead of demand forecasting. The proposed model finds a stock lower and upper limit for the relevant demand.

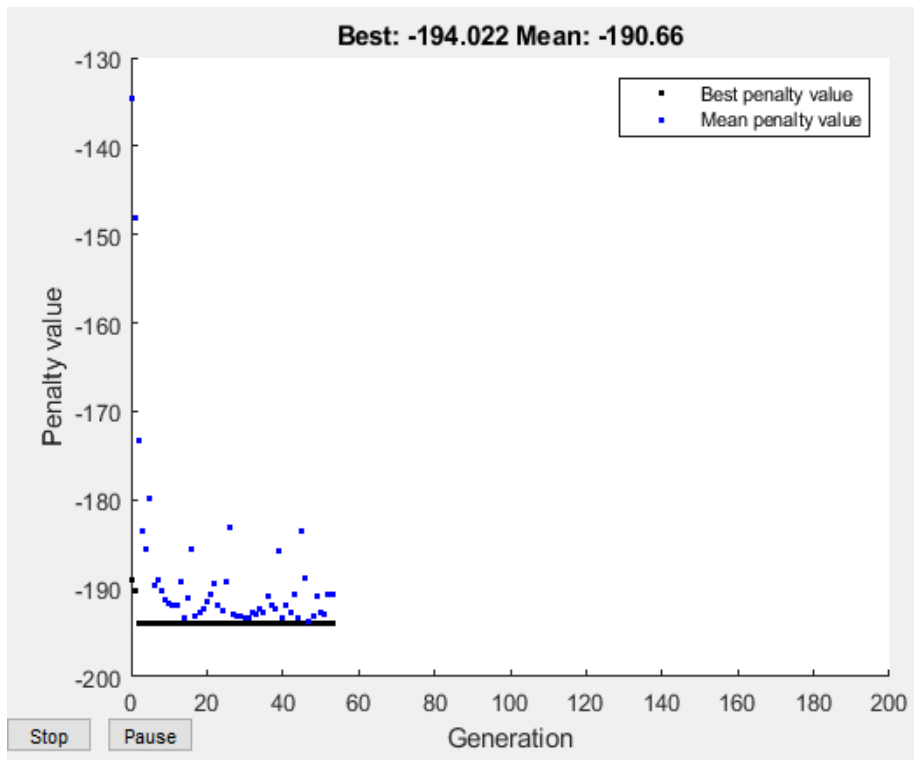

Fig. 8. Genetic algorithm graph

The proposed inventory model, which maximizes the average profit, works according to intermittent demand, and the appropriate upper stock and lower stock limits are determined by the Genetic Algorithm in Matlab. The Genetic Algorithm graph can be seen in Figure 8. The algorithm ended before the generation number reached 200. Because the differences between the results have started to decrease very much and continued in this way. Since the sales price is included in the model, the aim has been to maximize the average profit. The Genetic Algorithm in Figure 8 was run for 9776 seconds (approximately 163 minutes).
As a result, the lower stock limit was found to be 60 and the upper limit to 210 . The average profit is calculated as 194.0216 .

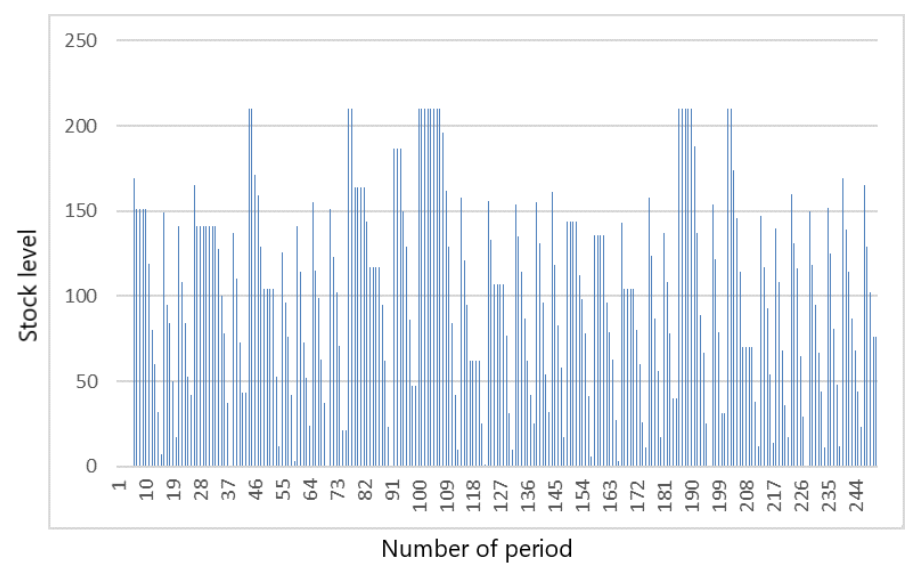

Fig. 9. Stock levels resulting from the proposed model

As seen in Figure 9, stock levels reached a maximum of 210. The reordering point is also set at 60 . Stock levels that maximize profit are calculated as in Figure 9. Thus, the difficulty of estimating the intermittent demand was tried to be overcome by determining stock levels.

\section{Conclusions and Recommendations}

This paper proposes an inventory model in order to minimize the cost increases and planning problems that may occur due to forecasting failures when demand estimation is difficult. This inventory model aims to find an upper and lower stock level that maximizes profit on Matlab with the help of the Genetic algorithm, taking into account the intermittent demand structure. The model calculates lower and upper stock limits with cost and profit values by maximizing profit within the framework of assumptions accepted. At the same time, information such as how many sales were made during which periods, the amount of lost sales, orders are also recorded in the model from period to period.

The proposed model is based on two important basic insights. First, the initial solution is created with the lower and upper stock limits randomly. Secondly, this solution is continued by improving with the help of Genetic Algorithm. Also, variable lead times were not added to the assumptions. The goal is to create a model that can cope with the variable nature of intermittent demand and reduce the cost of lost sales. With the correct stock limits, both inventory holding costs and lost sales costs will be reduced. Therefore, it is a good idea to avoid this difficult situation by using different approaches in situations where it is difficult to predict.

In future studies, delayed fulfillment can be added to the model instead of lost sales. In addition, the model can be updated for products with a certain shelf life and intermittent demand structure. The relevant model can also be run as a case of reverse logistics with returns. Another issue that can be investigated is the effect of lead time on stock limits and costs in a system with an intermittent demand structure.

\section{References}

Babai, M., Chen, H., Syntetos, A., \& Lengu, D. (2020). A compound-Poisson Bayesian approach for spare parts inventory forecasting. International Journal of Production Economics, 107954. 
Babai, M. Z., Syntetos, A., \& Teunter, R. (2014). Intermittent demand forecasting: An empirical study on accuracy and the risk of obsolescence. International Journal of Production Economics, 157, 212-219.

Boeringer, D. W., \& Werner, D. H. (2004). Particle swarm optimization versus genetic algorithms for phased array synthesis. IEEE Transactions on antennas and propagation, 52(3), 771-779.

Boutselis, P., \& McNaught, K. (2019). Using Bayesian Networks to forecast spares demand from equipment failures in a changing service logistics context. International Journal of Production Economics, 209, 325-333.

Haddow, B., \& Tufte, G. (2010). Goldberg DE Genetic Algorithms in Search, Optimization and Machine Learning.

Hasni, M., Babai, M., Aguir, M., \& Jemai, Z. (2019). An investigation on bootstrapping forecasting methods for intermittent demands. International Journal of Production Economics, 209, 20-29.

Jiang, P., Huang, Y., \& Liu, X. (2020). Intermittent demand forecasting for spare parts in the heavy-duty vehicle industry: a support vector machine model. International Journal of Production Research, 1-18.

Lolli, F., Gamberini, R., Regattieri, A., Balugani, E., Gatos, T., \& Gucci, S. (2017). Single-hidden layer neural networks for forecasting intermittent demand. International Journal of Production Economics, 183, 116-128.

Özçift, B. (2018). Otomotiv Yedek Parça Taleplerinin Tahmini İçin Bulanık Kümeleme Model Önerisi.

Pastore, E., Alfieri, A., \& Zotteri, G. (2019). An empirical investigation on the antecedents of the bullwhip effect: Evidence from the spare parts industry. International Journal of Production Economics, 209, 121-133.

Petropoulos, F., Kourentzes, N., \& Nikolopoulos, K. (2016). Another look at estimators for intermittent demand. International Journal of Production Economics, 181, 154161.

SAATÇİĞLU, D., \& ÖZÇAKAR, N. YAPAY SİNIR AĞLARI YÖNTEMI İLE ARALIKLI TALEP TAHMINI. Beykoz Akademi Dergisi, 4(1), 1-32.

Stip, J., \& Van Houtum, G.-J. (2020). On a method to improve your service BOMs within spare parts management. International Journal of Production Economics, 221, 107466.

Syntetos, A. (2001). Forecasting of intermittent demand. Brunel University Uxbridge,

Van der Auweraer, S., \& Boute, R. (2019). Forecasting spare part demand using service maintenance information. International Journal of Production Economics, 213, 138-149.

Yuna, F., \& Erkayman, B. (2019). A METAHEURISTIC APPROACH FOR AN INVENTORY MODEL WITH RANDOM DEMANDS. The 49th International Conference on Computers Industrial Engineering(CIE49) 